\title{
Vietnam and Iraq Wars: \\ Parallelism and Its Impact on U.S. Foreign Policy
}

\author{
Abdul Rohman \\ Dosen Program Studi Ilmu Komunikasi \\ Universitas Islam Indonesia (UII), Yogyakarta
}

\begin{abstract}
This article describes certain policies were developed in Vietnam and Iraq Wars in term of the quality of intelligence and congressional decision-making within two wars. Two similiraties are identified: a) the failure of intelligence in both war policies; and $b$ ) the controversy surrounding the policies to declare both wars. The Vietnam and Iraq wars have similarities in terms of the quality of intelligence and presidential decision-making to go to war. The fall and manipulation of intelligence and the increase of executive powers colored policies in both war declarations. Pluralism and elite-power theory shape U.S. foreign policy in which a few groups/elites govern the many. A critical perspective was presented to improve the quality of foreign policy by more listening to what allies consider being important and by gaining multilateral cooperation to overcome major multinational threats.
\end{abstract}

Keywords: Vietnam and Iraq wars, intelligence, the U.S. foreign policy

\begin{abstract}
Abstrak
Artikel ini menjelaskan beberapa kebijakan yang dikembangkan pada perang Vietnam dan Irak dalam hal kualitas intelijen dan pembuatan keputusan oleh Kongres. Ada dua kesamaan yang dapat diidentifikasi: a) kegagalan inteligen dalam kebijakan untuk perang Vietnam maupun Irak; dan b) kontroversi di sekitar kebijakan untuk mendeklarasikan kedua perang tersebut. Perang Vietnam dan perang Irak memiliki kesamaan dalam hal kualitas intelijen dan pengambilan keputusan di level presidensiil untuk melaksanakan perang. Kejatuhan dan manipulasi intelijen dan meningkatnya kekuatan eksekutif mewarnai kebijakan dalam deklarasi perang tersebut. Pluralisme dan teori elite-power membentuk kebijakan luar negeri Amerika Serikat, yaitu kelompok minoritas menguasai mayoritas. Perspektif kritis disajikan dalam artikel ini untuk mengembangkan kualitas kebijakan luar negeri Amerika Serikat yaitu dengan lebih memperhatikan apa yang dianggap penting oleh pihak Sekutu dan melakukan kerja sama multilateral untuk menyelesaikan ancaman internasional terbesar.
\end{abstract}

Kata Kunci: PerangVietnam dan perang Irak, inetelijen, kebijakan luar negeri Amerika Serikat 


\section{Introduction}

Although they occurred within different eras, the Vietnam and Iraq wars have commonalities in which certain policies were developed. This paper explains the similarities in term of the quality of intelligence and congressional decisionmaking within two wars. Then, it will relate pluralism and power-elite theory to war policy development and highlight how war syndrome affects U.S. foreign policy.

The failure of intelligence in both war policies is notorious. The information reported by the U.S. intelligence community was directly adopted by the relevant administration to declare wars. Then, when the intelligence information became known to the public, the executive branch manipulated it. For instance, the Johnson administration convinced the public through a televised address that the Gulf of Tonkin accident was a provocation for war in Vietnam (Cavanaugh, 2007:561564). Later, the Bush administration deceived the American public about the existence of weapons of mass destruction (WMD) by claiming that Iraq bought aluminum tubes to proliferate uranium for nuclear weapons. In fact, UN inspectors and experts concluded that there was no evidence that Iraq had WMD. The Bush administration also falsely stated that the Iraqi government trained al Qaeda to make bombs, poisons, and deadly gases (Cavanaugh, 2007). It seems that the U.S. intelligence connected too many dots to justify the invasion of Iraq (Betts, 2007).
Within both wars, Johnson and Bush manipulated intelligence, and were reluctant to closely examine information provided by the intelligence community that contradicted their views to pursue Congressional support for the use of military force (Lawrence, 2004:922).

Those situations indicate that there is almost always a tension between intelligence and executives (Jervis, 2010). In policymaking, executives need genuine information provided by intelligence. However, policymaking is often more political than information based. Leaders tend to politicize intelligence instead of relying upon it as information to create policies (Pillar, 2006). Therefore, in some circumstances the personal characteristics and personalities of leaders potentially influence policy development (Dyson 2007, Saunders 2009). Haney mentions that since individuals are part of the decisionmaking formulation, they can influence policy (Paul, 2008). Simply put, the Vietnam war was Johnson's war, and the Iraq war was Bush's war.

In relation to this, the leaders tried to silence the critics by limiting antiwar expression and freedom of information. For example, after Daniel Ellsberg leaked the Pentagon Papers to The New York Times, The Washington Post, and other newspapers, the government claimed that the publication would endanger national security and, therefore, it must be stopped. In 1972, then, this claim was discredited since government failed to 
prove it. Within the war on terror, the federal government formulated 15.6 million classified documents in 2001, or 81 percent more than in 2000, a year before the 9/11 attacks on the World Trade Center. Meanwhile, the number of declassified documents has steadily decreased by nearly 60 percent between 2000 and 2004 (Josh, 2005).

\section{Controversial Policies on War Declaration}

Both wars are also similar in term of how the policies to declare wars were controversial. Neither Johnson nor Bush obtained a formal war declaration from Congress. In each instance, the government insisted that war policy had to be made for national security reasons as particular justification for the executive branch to exceed the legislative branch's powers.

Therefore, a criticism of the Vietnam War policy development is that Congress failed to address administrative power to use military force to intervene in other countries. The Gulf of Tonkin Resolution, which passed 416 to $\mathrm{o}$ in the House and 88 to 2 in the Senate, granted President Johnson a blank check to use "all necessary measures" to face "aggression" in Vietnam (Hess in Paul, 2008:672).

In a slight difference from Johnson, Bush considered that Congressional support would be valuable for his Iraq policy. Nonetheless, his effort to gain backing from Congress was thin. Bush obviously kept advocating war in Iraq and suppressing Congressional opposition (Zelizer, 2010). Paul (2008) stated that the decision of war declaration always occurred as a tension of "commander-in-chief" and "congressional powers." Presidents tend to make decisions based on "legacy chains" that they learned from past events to form current policy issues, since previous outcomes might give certain suggestions and provide options that are possibly relevant to contemporary problems. Consequently, executive authority increases significantly over time and diminishes the representative's powers (Rudalevige, 2006).

War decision-making relates to pluralism and power-elite theory. Pluralism theory assumes that power in decision-making will move from one group to other groups to internalize their interests. Shafritz and Borick (2008: 41) stated that there is a closed linkage among military leaders and American industries indicated by companies in the defense field hire many retired military officers. Therefore, a conspiracy exists in the American military industry. Moreover, anti-democracy people exist within government administration and have certain pattern that perpetuates State Crimes Against Democracy (SCAD) practices (deHaven-Smith, 2010). 
Then, the power of elite theory explains that pluralism reduces citizen participation since the elite structure is closed, pyramidal, consensual, and unresponsive. According to this theory, society is divided into two classes: the few who govern and the many who are governed (Shafritz \& Borick, 2008: 41). Berinsky (2007) argues that elite conflicts shape opinions concerning war. When the elites express their disagreement, so does the public. The public tends to follow what the elites set for them based on certain self-interest interpretation. This evidence found in World War II and the second Iraq War in which the public had insufficient information to make a cost/benefit analysis concerning whether to support war or oppose it.

Cunningham (2002) used critical perspectives to explain the significance of comprehending the connection between war-making and political culture as well as economic, social, and political forces. He stated that purposive rationality to earn money displaces value rationality that challenges capitalism. Citing Horkeimer, Cunningham (2002:512) stated the “dialectic of Enlightment" which explains that human beings seek freedom and justice but also tend toward domination and restrictions on freedom. This argument is relevant to the decision to use U.S. military force in Vietnam to liberate Saigon from communist rule and in Baghdad to free people in Iraq from the tyranny of Saddam Hussein. However, these actions consequently created U.S. hegemony within two countries and led to hatred in Muslim countries. Inherent to this thought is what Habermas said in The Theory of Communicative Action in which capitalist societies are characterized by rationalizing tendencies and become more complex and differentiated.

National Security Strategy (NSS) develops certain ways based on their subjective rationalities to promote American power, "security"and "interest", and then allies with other modern capitalist economic systems to advance American business and corporate interests as occurred during the war era when American foreign policy applied realism which was defined as security interest in term of power and dominant economic interest.

One of the most controversial aspects of U.S. foreign policy is intervening in domestic affairs of other countries by using military force and the influence of leaders' belief in targeting states to be intervened and its preparation of intervention strategies (Saunders, 2009). For instance, in the Vietnam and Iraq wars, the U.S. government imposed democracy enforcement as a reason to combat communism and terrorism. In the Vietnam, domino theory was argued to explain that saving Saigon from communist rule would save other countries from communism; whereas in the war of terror it is assumed that governing democracy in the Middle East 
starting from Iraq will counter terrorism as it was believed that Iraq supported $\mathrm{Al}$ Qaeda and had weapons of massive destruction. The fact that both reasons had no sufficient evidence that can be threatening to U.S. foreign policy credibility.

\section{Conclusion}

Experiencing both wars should make U.S. foreign policymakers eager to listen to allies and operate multilaterally (Lawrence, 2004: 927). After winning the Cold War, the U.S. has been acting like the superpower country that has to be incharge as the liberator and stabilizer in the domestic affairs of all countries on the globe. Rationalizations for these actions are democracy promotion, law enforcement, liberation, national security, stability, and so forth. The military intervention used to achieve them calls debates among countries about what the motivation behind. Moreover, some countries consider that the U.S. is an enemy that must be against its policy and capitalism. Therefore, it is significant to form U.S. foreign policy based on what the allies consider as important and to increase multilateralism to address major international threats.

Figure 1. shows that the Vietnam and Iraq wars have similarities in terms of the quality of intelligence and presidential decision-making to go to war. The fall and manipulation of intelligence and the increase of executive powers colored policies in both war declarations. Pluralism and elite-power theory shape U.S. foreign policy in which a few groups/elites govern the many. A critical perspective was presented to improve the quality of foreign policy by more listening to what allies consider being important and by gaining multilateral cooperation to overcome major multinational threats. 


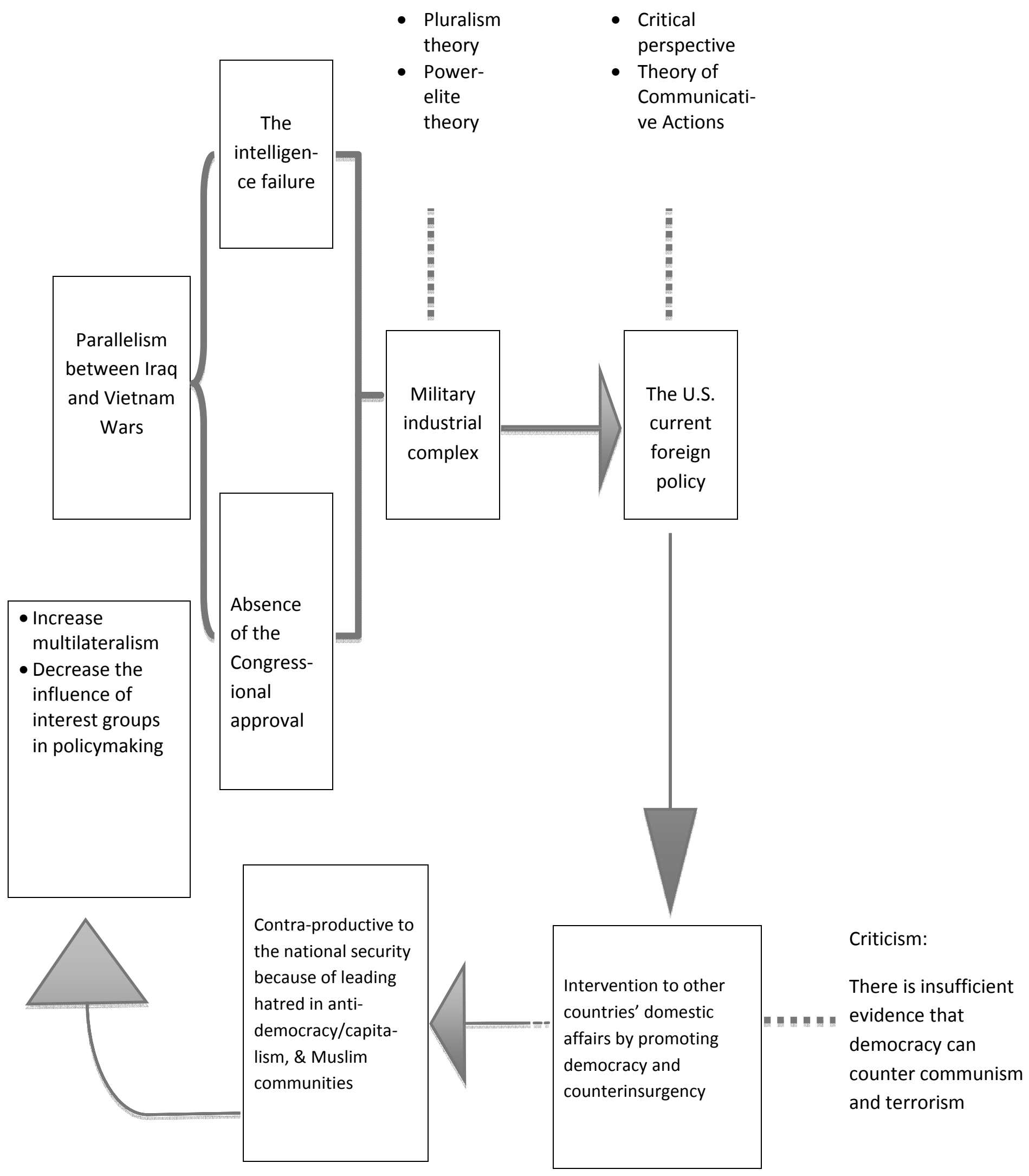

Figure 1. Parallelism between Vietnam and Iraq Wars and Its Impact on U.S. Foreign Policy 


\section{References}

Berinsky, A. J. 2007. "Assuming the Costs of War: Events, Elites, and American Support for Military Conflict". The Journal of Politics , 69 (4), pp. 975-997.

Betts, R. K. 2007. Two Faces of Intelligence Failure: September 11 and Iraq's Missing WMD. Political Science Quarterly , 122 (4), pp. 585-606.

Cavanaugh, J. M. 2007. From the "Red Juggernaut" to Iraqi WMD: Threat Inflation and How It Succeeds in the United States. Political Science Quarterly , 122 (4), pp. 555-584.

Cunningham, K. 2002. "A Critical Theory of the "Rationality" of US Foreign Policy: The Case of the American War in Vietnam”. New Political Science , 24 (4), pp. 509-523.

deHaven-Smith, L. 2010. "Beyond Conspiracy Theory: Pattern of High Crime in American Government”. American

Behavioral Scientist, 53 (6), pp. 795-825.
Dyson, S. B. 2007. “Alliances, Domestic Politics, and Leader Psychology: Why Did Britain Stay Out of Vietnam and Go into Iraq?”. Political Psychology, 28 (6), pp. 647-666.

Jervis, R. 2010. "Why Intelligence and Policymakers Clash". Political Science Quarterly, 125 (2), pp. 185-204.

Josh, K. 2005. "Government Secrecy". CQ Researcher, Dec 2, p. 1008.

Lawrence, M. A. 2004. "The Uses of Vietnam in the Age of Terrorism". International Journal , 59 (4), pp. 919-928.

Paul, C. 2008. "US Presidential War Powers: Legacy Chains in Military Intervention Decisionmaking”. Journal of Peace Research , 45 (5), pp. 665-679.

Pillar, P. R. 2006. "Intelligence, Policy, and the War in Iraq". Foreign Affairs , 85 (2), pp. 15-27.

Rudalevige, A. 2006. "The Contemporary Presidency: The Decline and Resurgence and Decline 9and Resurgence?) of Congress: Charting a New Imperial Presidency".Presidential Studies Quarterly , 36 (3), pp. 506-524. 
Saunders, E. N. 2009. "Transformative Choices. leaders and the origins of Intervention Strategy”. International Security , 34 (2), pp. 119-161.
Shafritz, Jay M., \& Borick, Christopher P. 2008. Introducing Public Policy. US: Pearson Education.

Zelizer, J. E. 2010. "Congress and the Politics of Troop Withdrawal". Diplomatic History , 34 (3), pp. 529-541. 